\title{
Association of Plasma Lactate Level With 28-day Mortality in Non-elderly and Elderly Sepsis Patients: A Retrospective Cohort Study Based on the Mimic-III Database
}

\author{
Yihua Dong \\ Wenzhou Medical University First Affiliated Hospital \\ Xiaoyang Miao \\ Wenzhou Medical University First Affiliated Hospital \\ Yufeng $\mathrm{Hu}$ \\ Wenzhou Medical University First Affiliated Hospital \\ Yueyue Huang \\ Wenzhou Medical University First Affiliated Hospital \\ Jie Chen \\ Wenzhou Medical University First Affiliated Hospital \\ Yingru Lu \\ Wenzhou Medical University First Affiliated Hospital \\ Jingye Pan ( $\sim$ wmupanjingye@126.com) \\ Wenzhou Medical University First Affiliated Hospital https://orcid.org/0000-0002-2367-1275
}

Research article

Keywords: sepsis, lactate, mortality, MIMIC database

Posted Date: July 8th, 2020

DOI: https://doi.org/10.21203/rs.3.rs-38386/v1

License: (c) (1) This work is licensed under a Creative Commons Attribution 4.0 International License. Read Full License 


\section{Abstract}

Purpose: The objective of this study is to assess the clinical usefulness of lactate as a predictor of 28-day mortality and the relationship between lactate and 28-day mortality in non-elderly ( $<65$ years) and elderly ( $\geq 65$ years) sepsis patients who were admitted to an intensive care unit (ICU).

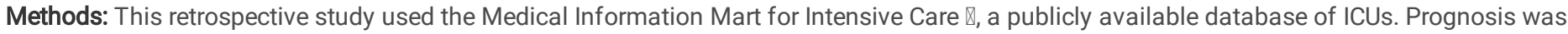
evaluated using receiver operating characteristic (ROC) analysis. Univariate and multivariable binary logistic regression models were used to identify the association lactate with 28-day mortality. We converted continuous variable lactate into a categorical variable based on tri-segment quantile to explore segmentation effects.

Results: The average age of 2848 patients was 68.01 years old, and about $55.40 \%$ of them were male. The overall 28 -day mortality was $30.41 \%$, and the rate in elderly patients was $65.82 \%$. Among non-survivors, the lactate level was significantly greater for the non-elderly than the elderly. Lactate level was positively associated with risk of 28-day mortality of the non-elderly sepsis patients ( $p$ for trend $<0.001$ ), but there was no significant association between lactate level and 28-day mortality in the elderly group ( $p$ for trend $=0.830$ ). The association between lactate and 28 -day mortality for sepsis patients without liver cirrhosis was stronger than for sepsis patients with liver cirrhosis (OR 1.28 vs. OR 1.10, $P=0.027)$.

Conclusion: Increased lactate level is associated with higher 28-day mortality in the non-elderly sepsis patients, but there is no significant association between the lactate level and 28-day mortality in the elderly group.

\section{Background}

The plasma lactate level is an important biomarker that reflects the oxygen metabolism of tissues. The root cause of septic shock is tissue hypoxia, and this leads to an increased level of glucose, anaerobic glycolysis, and lactate production [1]. Persistent hyperlactatemia, which suggests that tissue hypoxia has not been corrected, is associated with adverse outcome. Plasma lactate has been suggested as a biomarker for diagnosis and prognostic evaluation of sepsis [2]. An elevated level of plasma lactate during sepsis is associated with more severe disease and poor prognosis [3]. Previous studies revealed a relationship between lactate and mortality of patients with sepsis $[4,5]$ and indicated that patients who presented with lactate $>4 \mathrm{mmol} / \mathrm{L}$ are significantly associated with in-hospital mortality[4]. However, they only focus on the overall population and did not specifically address the relationship between different lactate level and mortality in different age groups. Therefore, this study aims to investigate whether lactate is independently associated with 28-day mortality and the relationship between lactate and 28-day mortality in non-elderly (<65 years) and elderly ( $\geq 65$ years) sepsis patients who were admitted to ICU.

\section{Methods}

\section{Data source}

The rapid development of medical information resources has made a large number of electronic health records available [6]. Analysis of these records has been a focus of significant research in medical research and related fields [7]. The Medical Information Mart for Intensive Care (MIMIC『), which we used for the present study, is a publicly available database developed by the Laboratory of Computational Physiology at the Massachusetts Institute of Technology. This database integrates comprehensive clinical data from ICU patients who received care at the Beth Israel Medical Center from 2001 to 2012. It has de-identified data on demography, vital signs, laboratory tests, medical records, imaging reports, drug use, and other clinically significant information [8]. Researchers and institutions around the world have published numerous studies based on analysis of the MIMIC- $\llbracket$ database [9-13].

\section{Study population}

The MIMIC- $₫$ database was used to identify all adults diagnosed with sepsis, severe sepsis, or septic shock with a first ICU admission. All included patients were at least 18 years-old and were hospitalized for at least $24 \mathrm{~h}$. Patients whose initial lactate and chart events were not recorded were excluded.

The gold standard used for diagnosis of sepsis was the 2001 consensus definition [14], which defines sepsis as infections consisting of 2 or more systemic inflammatory response syndrome (SIRS) criteria (temperature above $38^{\circ} \mathrm{C}$ or below $36^{\circ} \mathrm{C}$, heart rate greater than $90 / \mathrm{min}$, respiratory rate greater than $20 / \mathrm{min}$ or $\mathrm{PaCO} 2$ below $32 \mathrm{mmHg}$, and white blood cell count greater than 12,000 or less than $4000 \mathrm{cells} / \mathrm{mL}$ or $\mathrm{more}$ than $10 \%$ band forms) [14].

\section{Study design}

Independent variables (including demographic characteristics, major complications, major infection sites, laboratory data, vital signs, mortality prediction scores, and 28-day prognosis) were extracted from MIMIC- $₫$ via PostgreSQL, a structured query language with Navicat Premium 12. Baseline features of the patients were recorded within $24 \mathrm{~h}$ upon first admission to ICU. Lactate level was categorized as low, intermediate, or high. The primary outcome was 28-day mortality. 


\section{Methods of analysis}

Continuous variables are expressed as medians and inter-quartile range, and the Mann-Whitney U test was used for comparisons. Categorical variables are expressed as numbers and percentages, and were compared using the chi-square test or Fisher exact test. Prognosis was evaluated using receiver operating characteristic (ROC) analysis, and the ability of lactate to predict 28-day mortality was assessed by calculating the area under the ROC (AUROC). Youden's index was used to assess the performance of the diagnostic test, and the maximum point of Youden's index was used as the cut-off point (sensitivity + specificity -1 ).

Univariate and multivariate binary logistic regression were used to identify the association between lactate and 28-day mortality of sepsis patients. The Hosmer-Lemeshow test was used to evaluate the suitability of the model. The results were shown as ORs ( $95 \%$ Cls). To investigate the possibility of linearity, we converted continuous variable lactate into a categorical variable based on tri-segment quantile and calculated $\mathrm{P}$ values. Data were analyzed with the use of Empower (R) (www.empowerstats.com; X\&Y solutions inc.) and the statistical packages R (The R Foundation; http://www.r-project.org; version 3.4.3). For all analyses, a $\mathrm{P}$ value below 0.05 was considered significant.

\section{Results}

\section{Baseline characteristics}

There were 46,476 patients who were first admitted to the ICU, and 3512 had diagnoses of sepsis (ICD 995.91), severe sepsis (ICD 995.92), or septic shock (ICD 785.52; Figure 1). After exclusion of 5 patients who were younger than 18 years-old, 309 patients who were discharged from the ICU within 24 h, 4 patients who did not have chart event data, and 346 patients whose initial lactate levels were not measured, there were 2848 patients. Among these 2848 patients, 1249 were younger than 65 years and 1599 were 65 years or older.

The average age of 2848 patients was 68.01 years old, and about $55.40 \%$ of them were male. The overall 28 -day mortality rate was $30.4 \%$, and the rate in elderly patients was $65.82 \%$. Most patients in the non-elderly and elderly groups were male. The non-elderly patients stayed in ICU for more days, but the 28-day mortality was significantly greater in the elderly group. The baseline clinical and demographic characteristics of the survivors were compared to the non-survivors in each age group (Table 1). Analysis indicated the mortality rate increased with age within each age group, and that time in the ICU had a negative association with survivorship only in the elderly group. The non-survivors had a higher score of SAPSII, SOFA, LODS, OASIS, and lactate ( $<0.001$ for all). Analysis of major complications indicated the incidence of liver cirrhosis, chronic renal insufficiency and malignancy were significantly greater among non-survivors in each age group. Further analysis (Table 2) showed that the lactate was similar for elderly and non-elderly survivors ( $2.20 \mathrm{vs} .2 .10 \mathrm{mmol} / \mathrm{L}, P=0.062)$, but was greater in non-elderly non-survivors than elderly non-survivors (3.20 vs. $2.40 \mathrm{mmol} / \mathrm{L}, P<0.001)$.

\section{Predictive values of lactate and some severity scoring systems for 28-day mortality}

Table 3 lists the predictive values of lactate and some severity scoring systems in the two age groups for 28-day mortality. Their ROC curves are shown in Fig. 2 and Fig.3. The predictive value of lactate for 28-day mortality was 0.661 for the non-elderly group, and 0.553 for the elderly group. The predictive performance of QSOFA and SIRS for 28-day mortality increased after lactate was added, but there was no significant difference in the AUROC values of SAPSIIISOFA and LODS before and after lactate addition in the two age groups.

\section{Association of lactate with 28-day mortality for each age group}

In our study, there were 296 dead patients in the non-elderly group and 570 dead patients in the elderly group. We developed different models to examine the independent predicting value of lactate for 28-day mortality and used multivariate analysis to determine the impact of lactate on mortality in each group. The adjusted ORs (95\% Cls) for lactate were $1.16(1.09-1.23)$ and $1.03(0.98-1.08)$ for 28-day mortality in the non-elderly and elderly group, respectively.

To test the nonlinear trend between lactate and 28-day mortality in septic patients of each age group, we converted the continuous variable of lactate into a categorical variable according to tri-segment quantile in the models and divided lactate into three levels. Lactate levels in the nonelderly group were probably consistent with those in the elderly group. We initially used univariate logistic regression analysis to identify variables related to 28-day mortality. The subsequent multivariate logistic regression analysis, in which patients with low level of lactate were used as the reference group, indicated increased lactate level was associated with 28-day mortality. A significant trend in higher mortality was observed in patients with elevated lactate level compared to patients with less level of lactate in the non-elderly group ( $p<0.05$ for all). Lactate level was positively associated with risk of death at 28 days in the non-elderly group ( $p$ for trend $<0.001$ ), but there was no such correlation in the elderly group ( $\mathrm{p}$ for trend $=0.830)$.

\section{Subgroup Analyses}

A stratified analysis was conducted by baseline characteristics. In the subgroup analyses, we used sex, ethnicity, first care unit, severity scoring systems, comorbidities and major source of infection as the stratified variables to examined the associations between lactate and 28 -day mortality 
(Table 5). There was no significant difference in relationship between lactate and risk of 28-day mortality in the elderly group in the subgroup analyses. We observed significant changes in SAPSII, SOFA, liver cirrhosis and intra-peritoneal infection ( $p<0.05$ for all) (Fig.4). It was worth mentioning that we found significant inverse association of liver cirrhosis with 28-day mortality among the non-elderly sepsis patients. The lactate of the non-elderly patients without liver cirrhosis had a higher risk of 28-day mortality (OR 1.28, p < 0.0001). The association between lactate and 28 day mortality for sepsis patients without liver cirrhosis was stronger than for sepsis patients with liver cirrhosis in non-elderly group (OR 1.28 vs. OR $1.10, P=0.027$ for the interaction lactate* liver cirrhosis for 28-day mortality).

\section{Discussion}

In this study, we retrospectively analyzed the clinical characteristics, 28-day mortality rate, and the relationship of plasma lactate level with the prognosis of sepsis patients in different age groups in the MIMIC- $₫$ database. Our results suggested that higher lactate level was associated with higher 28-day mortality in the non-elderly sepsis patients, but there was no significant association in the elderly group.

The clinical mortality rate of sepsis is now higher than that of myocardial infarction and, except for heart disease, sepsis is the main cause of death in the ICU [15]. The ultimate cause of death from sepsis is organ dysfunction caused by the patient's reaction to the infection [16]. Because of their reduced immune responses and resistance, sepsis more common among the elderly. The prevalence and mortality of severe sepsis have increased significantly over time [17].

Most of these patients were from an emergency department, so those with high lactate levels were treated soon after admission. This may have contributed to the lower overall lactate levels in our study than in a previous study [18].

As a product of hypoxia and hypoperfusion, plasma lactate can be used to guide the judgment of fluid resuscitation and curative effect in patients with sepsis, and it is also an effective predictor of sepsis mortality [19]. Lactate is a well-known predictor of infection and trauma in patients and has been recognized as a biomarker for risk-stratification, especially in sepsis patients. Mikkelsen ME et al. [3] proposed initial serum lactate was associated with mortality independent of clinically apparent organ dysfunction and shock in patients admitted to the ED with severe sepsis. A previous study [20] reported that elevated lactate level was associated with poor prognosis for ICU patients after ruptured abdominal aortic aneurysm repair.

The elderly patients are more likely than the nonelderly to develop sepsis due to Gram-negative bacteria, especially among patients with pneumonia and fungal infections. Respiratory tract infections are also more common causes of sepsis in elderly patients [21]. Relative to the non-elderly, we found that elderly sepsis patients had a higher 28-day mortality rate and that sepsis was more likely to be caused by a respiratory tract infection, in agreement with previous studies $[18,22]$. In contrast, we found that sepsis in non-elderly patients was more likely to be caused by skin and soft tissue infections.

The major indicators of poor prognosis in elderly sepsis patients are shock, elevated plasma lactate, and organ failure (especially of the respiratory system or heart) [23]. In addition, previous research indicated that advanced age is an independent risk factor for severe sepsis and death from sepsis [24]. Our multivariate adjusted logistic regression analysis showed that lactate level was an independent risk factor for 28-day mortality for non-elderly sepsis patients, but this relationship was not significant for the elderly. This might be a result of blunted inflammatory responses in the elderly.

We were surprised to find that the association between lactate and 28-day mortality for sepsis patients without liver cirrhosis was stronger than in sepsis with liver cirrhosis in non-elderly group. Some patients have high plasma lactate levels due to liver dysfunction leading to lactate removal dysfunction, but patients with normal or moderate lactate levels may have a higher risk of death[25], the interpretation of serum lactate levels is often complex. Therefore, a randomized controlled trial is necessary to examine whether liver insufficiency affects the relationship between lactate and the risk of death.

There are some limitations in this study. First, the patient information we used for analysis was only from the MIMIC-III database. The results may have bias, but the advantage of population size in our study may reduce the bias. Second, we could not analyze data from patients excluded due to missing lactate values. Although this is one of our potential limitations, we think that the characteristic of study with a relatively large number of patients may reduce the drawback. In addition, we compared the 28-day mortality in patients with lactate and without lactate values. There was no significant difference between the two groups $(\mathrm{p}=0.281)$. Finally, further forward-looking, large sample validation and risk grading studies are necessary to conduct to find more simple and effective prediction methods and achieve targeted interventions to reduce the incidence of death.

\section{Conclusions}

A significant trend in higher mortality was observed in patients with elevated lactate levels compared to patients with less level of lactate in the nonelderly group. Lactate level was positively associated with risk of 28-day mortality of the non-elderly sepsis patients, but there was no significant association between lactate level and 28-day mortality in the elderly group. 


\section{Abbreviations}

ICU: Intensive Care Unit; MIMIC-III: the Medical Information Mart for Intensive Care III; ROC: receiver operating characteristic; AUROC: the area under the receiver operating characteristic curve; OR: odd ratio; SpO2, peripheral capillary oxygen saturation; MICU, medical intensive care unit; CCU, coronary care unit; TSICU, trauma surgical intensive care unit; CSRU, cardiac surgery recovery unit; SICU, surgical intensive care unit; SAPSII, simplified acute physiology score II;SOFA, sequential organ failure assessment; LODS: logistic organ dysfunction system; OASIS: oxford acute severity of illness score; QSOFA: quick sepsis related organ failure assessment; SIRS: systemic inflammatory response syndrome.

\section{Declarations}

\section{Acknowledgments}

The authors would like to thank MIMIC $\otimes$ program for access to the database.

\section{Funding}

No funding was obtained for this study.

\section{Availability of data and materials}

The datasets analyzed during the current study are available in https://github.com/MIT-LCP/mimic-code/tree/master/concepts.

\section{Authors' contributions}

YHD designed the methods and experiments, and contributed to the writing of manuscript. XYM and YFH cleaned the data. YYH, JC and YRL provided guidance and reviewed the manuscript critically. JYP supervised the study and revised the paper. All authors read and approved the final manuscript.

\section{Ethics declarations}

\section{Ethics approval and consent to participate}

Ethical consent was not required in this study, since the MIMIC $₫$ data were analyzed namelessly.

\section{Consent for publication}

The manuscript does not include individual person's data.

\section{Competing interests}

The authors declare that they have no competing interests.

\section{Publisher's Note}

Springer Nature remains neutral with regard to jurisdictional claims in published maps and institutional affiliations.

\section{References}

1. Doherty JR, Cleveland JL. Targeting lactate metabolism for cancer therapeutics. J Clin Invest. 2013;123(Suppl 9):3685-92.

2. John L Moran, John Santamaria. Reconsidering lactate as a sepsis risk biomarker. PLoS One, 2017, 12(10): e0185320.

3. Mikkelsen ME, Miltiades AN, Gaieski DF, Goyal M, Fuchs BD, Shah CV, Bellamy SL, Christie JD. Serum lactate is associated with mortality in severe sepsis independent of organ failure and shock. Crit Care Med. 2009;37(Suppl 5):1670-7.

4. Brian Casserly, Gary S Phillips, Christa Schorr, R Phillip Dellinger, Sean R Townsend, Tiffany M Osborn, Konrad Reinhart, Narendran Selvakumar, Mitchell M Levy. Lactate measurements in sepsis-induced tissue hypoperfusion: results from the Surviving Sepsis Campaign database. Crit Care Med. 2015;43(3):567-73.

5. Tae Gun Shin, Ik Joon Jo, Sung Yeon Hwang, Kyeongman Jeon, Gee Young Suh, Euna Choe, Young Kun Lee, Tae Rim Lee, Won Chul Cha, Min Seob Sim. Comprehensive interpretation of central venous oxygen saturation and blood lactate Levels during resuscitation of patients with severe sepsis and septic shock in the emergency department. Shock.2016:45(1):4-9.

6. Zhang L, Wang H, Li Q, Zhao MH, Zhan QM. Big data and medical research in China. BMJ. 2018; doi: 10.1136/bmj.j5910.

7. Raghupathi W, Raghupathi V. Big data analytics in healthcare: promise and potential. Health Inf Sci Syst. 2014;2:3. doi: 10.1186/2047-2501-2-3. 


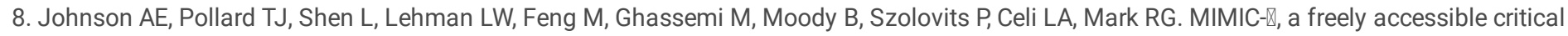
care database. Sci Data. 2016; doi: 10.1038/sdata.2016.35.

9. Ghassemi M, Wu M, Hughes MC, Szolovits P, Doshi-velez F. Predicting intervention onset in the ICU with switching state space models. AMIA Summits TransI Sci Proc. 2017; 2017: 82-91.

10. Janice Pan, Shaffer R, Sinno Z, Tyler M, Ghosh J. The obesity paradox in ICU patients. Conf Proc IEEE Eng Med Biol Soc. 2017;2017:3360-4.

11. Sandfort V, Johnson AEW, Kunz LM, Vargas JD, Rosing DR. Prolonged elevated heart rate and 90-day survival in acutely ill patients: data from the MIMIC- $\llbracket$ database. J Intensive Care Med. 2019;34(Suppl 8):622-9.

12. Yao S, Jiang X, Sun C, Zheng Z, Wang B, Wang T. External validation and improvement of life score as a prediction tool in critically ill cirrhosis patients. Hepatol Res. 2018;48(Suppl 11):905-13.

13. Hu ZD, Wei TT, Tang QQ, Fu HT, Yang M, Ma N, Wang LL, Qin BD, Zhou L, Zhong RQ. Prognostic value of red blood cell distribution width in acute pancreatitis patients admitted to intensive care units: an analysis of a publicly accessible clinical database MIMIC II. Clin Chem Lab Med. 2016;54(Suppl 7):e195-7.

14. Levy MM, Fink MP, Marshall JC, Abraham E, Angus D, Cook D, Cohen J, Opal SM, Vincent JL, Ramsay G. 2001 SCCM/ESICM/ACCP/ATS/SIS international sepsis definitions conference. Intensive Care Med 2001;2003:530-8.

15. Berg RM, Plovsing RR. Near-infrared spectroscopy versus transcranial Doppler ultrasound for assessing dynamic cerebral autoregulation by transfer function analysis in sepsis. Scand J Clin Lab Invest. 2016;76(Suppl 1):88-91.

16. Shankar-Hari M, Phillips GS, Levy ML, Seymour CW, Liu VX, Deutschman CS, Angus DC, Rubenfeld GD, Singer M, Sepsis Definitions Task Force. Developing a new definition and assessing new clinical criteria for septic shock: for the Third International Consensus definitions for sepsis and septic shock (Sepsis-3). JAMA. 2016;315(Suppl 8):775-87.

17. Dombrovskiy VY, Martin AA, Sunderram J, Paz HL. Rapid increase in hospitalization and mortality rates for severe sepsis in the United States: a trend analysis from 1993 to 2003. Crit Care Med. 2007;35(Suppl 5):1244-50.

18. Cheng HH, Chen FC, Change MW, Kung CT, Cheng CY, Tsai TC, Hsiao SY, Su CM. Difference between elderly and non-elderly patients in using serum lactate level to predict mortality caused by sepsis in the emergency department. Medicine (Baltimore). 2018;97(Suppl 13):e0209. doi: 10.1097/MD.0000000000010209.

19. Garcia-Alvarez M, Marik P, Bellomo R. Sepsis-associated hyperlactatemia. Crit Care, 2014, 18(5): 503.

20. Singhal R, Coghill JE, Guy A, Bradbury AW, Adam DJ, Scriven JM. Serum lactate and base deficit as predictors of mortality after ruptured abdominal aortic aneurysm repair. Eur J Vasc Endovasc Surg.2005;30(Suppl 3):263-6.

21. Martin GS, Mannino DM, Moss M. The effect of age on the development and outcome of adult sepsis. Crit Care Med. 2006;34(Suppl 1):15-21.

22. Blot S, Cankurtaran M, Petrovic M, Vandijck D, Lizy C, Decruyenaere J, Danneels C, Vandewoude K, Piette A, Vershraegen G, et al. Epidemiology and outcome of nosocomial bloodstream infection in elderly critically ill patients: a comparison between middle-aged, old, and very old patients. Crit Care Med. 2009;37(Suppl 5):1634-41.

23. Liang SY. Sepsis and other infectious disease emergencies in the elderly. Emerg Med Clin North Am. 2016;34(Suppl 3):501-22.

24. Angus DC, Linde-Zwirble WT, Lidicker J, Clermont G, Carcillo J, Pinsky MR. Epidemiology of severe sepsis in the United States: analysis of incidence, outcome, and associated costs of care. Crit Care Med. 2001;29(Suppl 7):1303-10.

25. Haas SA, Lange T, Saugel B, Petzoldt M, Fuhrmann V, Metschke M, Kluge S. Severe hyperlactatemia, lactate clearance and mortality in unselected critically ill patients. Intensive Care Med. 2016;42(2):202-10.

\section{Tables}

Table 1. Baseline characteristics and clinical outcomes of patients in the two age groups. 


\begin{tabular}{|c|c|c|c|c|c|c|c|}
\hline \multirow[t]{2}{*}{ Variable } & \multicolumn{3}{|c|}{ Non-elderly $(n=1249)$} & \multicolumn{3}{|c|}{$\begin{array}{l}\text { Elderly }(n=1599) \otimes 9)<0.001 * \square<0.001 * \\
! 7\end{array}$} & \multirow[t]{2}{*}{$P$ value } \\
\hline & Survivors & Non-survivors & P value & Survivors & Non-survivors & $P$ value & \\
\hline Age (years) & $\begin{array}{l}52.99(43.54- \\
59.53)\end{array}$ & $\begin{array}{l}55.89(48.89- \\
61.17)\end{array}$ & $<0.001^{*}$ & $\begin{array}{l}78.23(71.77- \\
84.58)\end{array}$ & $\begin{array}{l}80.43(72.48- \\
85.82)\end{array}$ & $0.009^{*}$ & $<0.001^{\star}$ \\
\hline Sex & & & 0.353 & & & 0.354 & $0.023^{*}$ \\
\hline Male & $544(57.08 \%)$ & $178(60.14 \%)$ & & $542(52.67 \%)$ & $314(55.09 \%)$ & & \\
\hline Female & $409(42.92 \%)$ & $118(39.86 \%)$ & & $487(47.33 \%)$ & $256(44.91 \%)$ & & \\
\hline ICU length of stay (d) & $4.73(2.43-12.12)$ & $5.03(2.27-10.16)$ & 0.196 & $3.69(2.09-8.43)$ & $4.48(2.30-9.00)$ & 0.048 & $<0.001^{*}$ \\
\hline Lactate (mmol/L) & $2.10(1.40-3.40)$ & $3.20(1.93-5.18)$ & $<0.001^{*}$ & $2.20(1.50-3.50)$ & $2.40(1.68-4.00)$ & $<0.001^{*}$ & 0.852 \\
\hline \multicolumn{8}{|l|}{ Scoring system } \\
\hline SAPSII & $\begin{array}{l}36.00(27.00- \\
46.00)\end{array}$ & $\begin{array}{l}53.50(42.00- \\
64.00)\end{array}$ & $<0.001^{*}$ & $\begin{array}{l}45.00(37.00- \\
54.00)\end{array}$ & $\begin{array}{l}55.00(47.00- \\
66.00)\end{array}$ & $<0.001^{*}$ & $<0.001^{*}$ \\
\hline SOFA & $6.00(4.00-9.00)$ & $11.00(7.00-14.00)$ & $<0.001^{\star}$ & $6.00(4.00-8.00)$ & $8.00(6.00-11.00)$ & $<0.001^{*}$ & $0.013^{*}$ \\
\hline LODS & $4.00(2.00-6.00)$ & $6.00(4.00-8.00)$ & $<0.001^{\star}$ & $4.00(2.00-5.00)$ & $5.00(3.00-7.00)$ & $<0.001^{*}$ & 0.557 \\
\hline OASIS & $\begin{array}{l}34.00(27.00- \\
41.00)\end{array}$ & $\begin{array}{l}40.00(34.25- \\
47.00)\end{array}$ & $<0.001^{*}$ & $\begin{array}{l}37.00(31.00- \\
43.00)\end{array}$ & $\begin{array}{l}43.00(37.00- \\
48.00)\end{array}$ & $<0.001^{*}$ & $<0.001^{*}$ \\
\hline QSOFA & & & $<0.001^{*}$ & & & $<0.001^{*}$ & $<0.001^{*}$ \\
\hline 0 & $10(1.05 \%)$ & $3(1.01 \%)$ & & $10(0.97 \%)$ & $0(0.00 \%)$ & & \\
\hline 1 & $144(15.11 \%)$ & $17(5.74 \%)$ & & $135(13.12 \%)$ & $49(8.60 \%)$ & & \\
\hline 2 & $669(70.20 \%)$ & $215(72.64 \%)$ & & $661(64.24 \%)$ & $345(60.52 \%)$ & & \\
\hline 3 & $130(13.64 \%)$ & $61(20.61 \%)$ & & $223(21.67 \%)$ & $176(30.88 \%)$ & & \\
\hline SIRS & & & 0.342 & & & $0.001^{*}$ & $0.001^{\star}$ \\
\hline 0 & $2(0.21 \%)$ & $0(0.00 \%)$ & & $1(0.10 \%)$ & $0(0.00 \%)$ & & \\
\hline 1 & $27(2.83 \%)$ & $5(1.69 \%)$ & & $28(2.72 \%)$ & $8(1.40 \%)$ & & \\
\hline 2 & $94(9.86 \%)$ & $31(10.47 \%)$ & & $156(15.16 \%)$ & $55(9.65 \%)$ & & \\
\hline 3 & $342(35.89 \%)$ & $99(33.45 \%)$ & & $399(38.78 \%)$ & $224(39.30 \%)$ & & \\
\hline 4 & $488(51.21 \%)$ & $161(54.39 \%)$ & & $445(43.24 \%)$ & $283(49.65 \%)$ & & \\
\hline Ethnicity & & & 0.531 & & & $0.009^{\star}$ & $<0.001^{*}$ \\
\hline White & $650(68.21 \%)$ & $201(67.91 \%)$ & & $819(79.59 \%)$ & $428(75.09 \%)$ & & \\
\hline Black & $109(11.44 \%)$ & $28(9.46 \%)$ & & $75(7.29 \%)$ & $28(4.91 \%)$ & & \\
\hline Asian & $34(3.57 \%)$ & $6(2.03 \%)$ & & $33(3.21 \%)$ & $17(2.98 \%)$ & & \\
\hline Hispanic & $50(5.25 \%)$ & $8(2.70 \%)$ & & $20(1.94 \%)$ & $9(1.58 \%)$ & & \\
\hline Other or unknown & $110(11.54 \%)$ & $53(17.91 \%)$ & & $82(7.97 \%)$ & $88(15.44 \%)$ & & \\
\hline First care unit & & & 0.194 & & & 0.741 & $0.02^{*}$ \\
\hline MICU & $642(67.37 \%)$ & $210(70.94 \%)$ & & $739(71.82 \%)$ & $398(69.82 \%)$ & & \\
\hline $\mathrm{CCU}$ & $64(6.72 \%)$ & $20(6.76 \%)$ & & $70(6.80 \%)$ & $61(10.70 \%)$ & & \\
\hline TSICU & $66(6.92 \%)$ & $21(7.09 \%)$ & & $74(7.19 \%)$ & $40(7.02 \%)$ & & \\
\hline CSRU & $25(2.62 \%)$ & $6(2.03 \%)$ & & $30(2.92 \%)$ & $20(3.51 \%)$ & & \\
\hline SICU & $156(16.37 \%)$ & $39(13.18 \%)$ & & $116(11.27 \%)$ & $51(8.95 \%)$ & & \\
\hline Admission type & & & 0.487 & & & 0.287 & 0.071 \\
\hline Emergency & 894(93.81\%) & $281(94.93 \%)$ & & $979(95.14 \%)$ & $549(96.32 \%)$ & & \\
\hline
\end{tabular}




\begin{tabular}{|c|c|c|c|c|c|c|c|}
\hline Elective & $41(4.30 \%)$ & $9(3.04 \%)$ & & $39(3.79 \%)$ & $13(2.28 \%)$ & & \\
\hline Urgent & 18(1.89\%) & $6(2.03 \%)$ & & $11(1.07 \%)$ & $8(1.40 \%)$ & & \\
\hline \multicolumn{8}{|l|}{ Initial vital signs } \\
\hline Heart rate (beats/min) & $\begin{array}{l}96.61(84.67- \\
109.36)\end{array}$ & $\begin{array}{l}98.58(86.72- \\
112.71)\end{array}$ & $0.031^{*}$ & $\begin{array}{l}87.00(75.81- \\
98.77)\end{array}$ & $\begin{array}{l}90.85(77.46- \\
105.41)\end{array}$ & $<0.001^{*}$ & $<0.001^{*}$ \\
\hline $\begin{array}{l}\text { Mean blood pressure } \\
(\mathrm{mmHg})\end{array}$ & $\begin{array}{l}74.18(69.43- \\
80.44)\end{array}$ & $\begin{array}{l}72.31(66.19- \\
78.57)\end{array}$ & $<0.001^{*}$ & $\begin{array}{l}71.03(66.02- \\
76.90)\end{array}$ & $\begin{array}{l}69.13(64.48- \\
74.30)\end{array}$ & $<0.001^{*}$ & $<0.001^{*}$ \\
\hline $\begin{array}{l}\text { Respiratory rate } \\
\text { (breaths/min) }\end{array}$ & $\begin{array}{l}20.98(17.94- \\
24.21)\end{array}$ & $\begin{array}{l}22.25(19.10- \\
26.11)\end{array}$ & $<0.001^{*}$ & $\begin{array}{l}20.47(17.79- \\
23.49)\end{array}$ & $\begin{array}{l}21.39(18.38- \\
25.06)\end{array}$ & $<0.001^{*}$ & $0.013^{\star}$ \\
\hline Body temperature $\left({ }^{\circ} \mathrm{C}\right)$ & $\begin{array}{l}37.18(36.67- \\
37.75)\end{array}$ & $\begin{array}{l}36.76(36.22- \\
37.37)\end{array}$ & $<0.001^{*}$ & $\begin{array}{l}36.79(36.35- \\
37.29)\end{array}$ & $\begin{array}{l}36.65(36.16- \\
37.14)\end{array}$ & $<0.001^{*}$ & $<0.001^{*}$ \\
\hline SpO2 (\%) & $\begin{array}{l}97.21(95.88- \\
98.48)\end{array}$ & $\begin{array}{l}\text { 96.59(95.01- } \\
98.19)\end{array}$ & $<0.001^{*}$ & $\begin{array}{l}97.30(95.96- \\
98.50)\end{array}$ & $\begin{array}{l}97.04(95.22- \\
98.51)\end{array}$ & 0.004 & 0.143 \\
\hline \multicolumn{8}{|l|}{ Major comorbidities } \\
\hline Hypertension & $388(40.71 \%)$ & $112(37.84 \%)$ & 0.378 & $642(62.39 \%)$ & $340(59.65 \%)$ & 0.281 & $<0.001^{*}$ \\
\hline Liver cirrhosis & $88(9.23 \%)$ & $108(36.49 \%)$ & $<0.001^{*}$ & $37(3.60 \%)$ & $40(7.02 \%)$ & $0.002^{*}$ & $<0.001^{*}$ \\
\hline Congestive heart failure & $168(17.63 \%)$ & $60(20.27 \%)$ & 0.304 & $436(42.37 \%)$ & $252(44.21 \%)$ & 0.477 & $<0.001^{*}$ \\
\hline Chronic renal insufficiency & $520(54.56 \%)$ & $216(72.97 \%)$ & $<0.001^{*}$ & $656(63.75 \%)$ & $421(73.86 \%)$ & $<0.001^{*}$ & $<0.001^{*}$ \\
\hline Cerebrovascular disease & $67(7.03 \%)$ & $22(7.43 \%)$ & 0.814 & $96(9.33 \%)$ & $63(11.05 \%)$ & 0.270 & $0.008^{\star}$ \\
\hline Diabetes mellitus & $253(26.55 \%)$ & $74(25.00)$ & 0.597 & $355(34.50 \%)$ & 199(34.91\%) & 0.868 & $<0.001^{*}$ \\
\hline Malignancy & $82(8.60 \%)$ & $67(22.64 \%)$ & $<0.001^{*}$ & 103(10.01\%) & $125(21.93 \%)$ & $<0.001^{*}$ & 0.069 \\
\hline \multicolumn{8}{|l|}{ Major source of infection } \\
\hline Respiratory tract & $281(29.49 \%)$ & $83(28.04 \%)$ & 0.633 & $335(32.56 \%)$ & $202(35.44 \%)$ & 0.243 & $0.011^{*}$ \\
\hline Urinary tract & $44(4.62 \%)$ & $0(0 \%)$ & $<0.001^{*}$ & $40(3.89 \%)$ & $9(1.58 \%)$ & $0.01^{*}$ & 0.495 \\
\hline Skin and soft tissue & $120(12.59 \%)$ & $19(6.42 \%)$ & $0.003^{*}$ & $86(8.36 \%)$ & $28(4.91 \%)$ & $0.01^{*}$ & $<0.001^{*}$ \\
\hline Intra-abdomen & $149(15.63 \%)$ & $58(19.59 \%)$ & 0.11 & 186(18.08\%) & $75(13.16 \%)$ & $0.011^{*}$ & 0.858 \\
\hline 28-day mortality & $296(23.70 \%)$ & & & $570(35.65 \%)$ & & & $<0.001^{*}$ \\
\hline
\end{tabular}

${ }^{*} P<0.05$

SAPSII, simplified acute physiology score II; SOFA, sequential organ failure assessment; LODS: logistic organ dysfunction system; OASIS: oxford acute severity of illness score; QSOFA: quick sepsis related organ failure assessment; SIRS: systemic inflammatory response syndrome; MICU, medical intensive care unit; CCU, coronary care unit; TSICU, trauma surgical intensive care unit; CSRU, cardiac surgery recovery unit; SICU, surgical intensive care unit; $\mathrm{SpO}_{2}$, peripheral capillary oxygen saturation.

Table 2. Lactate levels in survivors and non-survivors of the two age groups.

\begin{tabular}{|lllllll|}
\hline Variable & Survivors $(\mathrm{n}=1982)$ & & \multicolumn{3}{l|}{ Non-survivors $(\mathrm{n}=\mathbf{8 6 6})$} \\
\cline { 2 - 7 } & Non-elderly $(\mathrm{n}=\mathbf{9 5 3})$ & Elderly $(\mathrm{n}=1029)$ & P value & Non-elderly( $\mathrm{n}=296)$ & Elderly $(\mathrm{n}=570)$ & P value \\
\hline Lactate $(\mathrm{mmol} / \mathrm{L})$ & $2.10(1.40-3.40)$ & $2.20(1.50-3.50)$ & 0.062 & $3.20(1.92-5.18)$ & $2.40(1.68-4.00)$ & $<0.001^{*}$ \\
\hline
\end{tabular}

${ }^{*} P<0.05$

Table 3. AUC of lactate and some scoring systems for predicting 28-day mortality. 


\begin{tabular}{|c|c|c|c|c|c|c|c|c|c|c|}
\hline & \multicolumn{5}{|l|}{ Non-elderly } & \multicolumn{5}{|l|}{ Elderly } \\
\hline & AUC (95\% Cl) & Sensitivity & Specificity & $\begin{array}{l}\text { Youden's } \\
\text { index }\end{array}$ & $P$ value & AUC (95\%Cl) & Sensitivity & Specificity & $\begin{array}{l}\text { Youden's } \\
\text { index }\end{array}$ & $\begin{array}{l}P \\
\text { value }\end{array}$ \\
\hline SAPSII & $\begin{array}{l}0.797(0.769- \\
0.824)\end{array}$ & 0.710 & 0.739 & 0.448 & 0.424 & $\begin{array}{l}0.704(0.678- \\
0.730)\end{array}$ & 0.775 & 0.539 & 0.315 & 0.587 \\
\hline SAPSII*LAC & $\begin{array}{l}0.800(0.773- \\
0.827)\end{array}$ & 0.784 & 0.675 & 0.459 & & $\begin{array}{l}0.705(0.679- \\
0.731)\end{array}$ & 0.756 & 0.566 & 0.322 & \\
\hline SOFA & $\begin{array}{l}0.761(0.730- \\
0.792)\end{array}$ & 0.588 & 0.796 & 0.384 & 0.157 & $\begin{array}{l}0.657(0.629- \\
0.685)\end{array}$ & 0.663 & 0.579 & 0.242 & 0.616 \\
\hline SOFA*LAC & $\begin{array}{l}0.767(0.736- \\
0.798)\end{array}$ & 0.628 & 0.787 & 0.415 & & $\begin{array}{l}0.658(0.630- \\
0.686)\end{array}$ & 0.602 & 0.645 & 0.247 & \\
\hline LODS & $\begin{array}{l}0.723(0.690- \\
0.755)\end{array}$ & 0.737 & 0.619 & 0.356 & 0.057 & $\begin{array}{l}0.651(0.623- \\
0.679)\end{array}$ & 0.460 & 0.754 & 0.214 & 0.057 \\
\hline LODS*LAC & $\begin{array}{l}0.737(0.705- \\
0.769)\end{array}$ & 0.689 & 0.665 & 0.355 & & $\begin{array}{l}0.657(0.629- \\
0.685)\end{array}$ & 0.507 & 0.729 & 0.236 & \\
\hline OASIS & $\begin{array}{l}0.696(0.663- \\
0.729)\end{array}$ & 0.750 & 0.531 & 0.281 & $0.012^{*}$ & $\begin{array}{l}0.683(0.656- \\
0.709)\end{array}$ & 0.744 & 0.513 & 0.257 & 0.431 \\
\hline OASIS*LAC & $\begin{array}{l}0.717(0.683- \\
0.750)\end{array}$ & 0.710 & 0.602 & 0.312 & & $\begin{array}{l}0.685(0.659- \\
0.712)\end{array}$ & 0.723 & 0.548 & 0.271 & \\
\hline QSOFA & $\begin{array}{l}0.569(0.533- \\
0.606)\end{array}$ & 0.932 & 0.162 & 0.094 & $<0.001^{*}$ & $\begin{array}{l}0.561(0.532- \\
0.591)\end{array}$ & 0.309 & 0.783 & 0.092 & $0.003^{*}$ \\
\hline QSOFA*LAC & $\begin{array}{l}0.668(0.633- \\
0.704)\end{array}$ & 0.757 & 0.503 & 0.259 & & $\begin{array}{l}0.591(0.561- \\
0.620)\end{array}$ & 0.442 & 0.710 & 0.153 & \\
\hline SIRS & $\begin{array}{l}0.516(0.479- \\
0.554)\end{array}$ & 0.544 & 0.488 & 0.032 & $<0.001^{*}$ & $\begin{array}{l}0.546(0.517- \\
0.575)\end{array}$ & 0.890 & 0.180 & 0.069 & $0.038^{\star}$ \\
\hline SIRS*LAC & $\begin{array}{l}0.661(0.626- \\
0.697)\end{array}$ & 0.723 & 0.523 & 0.246 & & $\begin{array}{l}0.569(0.540- \\
0.598)\end{array}$ & 0.861 & 0.236 & 0.098 & \\
\hline Lactate & $\begin{array}{l}0.661(0.626- \\
0.697)\end{array}$ & 0.723 & 0.523 & 0.246 & & $\begin{array}{l}0.553(0.523- \\
0.582)\end{array}$ & 0.204 & 0.880 & 0.083 & \\
\hline
\end{tabular}

${ }^{*} P<0.05$

Table 4. Relationship between lactate and 28-day mortality in different models. 


\begin{tabular}{|c|c|c|c|c|c|c|}
\hline & Non-adjusted & & Adjusted I & & Adjusted II & \\
\hline & OR $(95 \% \mathrm{Cl})$ & $P$ value & OR $(95 \% \mathrm{Cl})$ & $P$ value & OR $(95 \% \mathrm{Cl})$ & $P$ value \\
\hline \multicolumn{7}{|l|}{ Non-elderly } \\
\hline Lactate (mmol/L) & $1.28(1.21-1.35)$ & $<0.001^{*}$ & $1.29(1.22-1.37)$ & $<0.001^{*}$ & $1.16(1.09-1.23)$ & $<0.001^{*}$ \\
\hline \multicolumn{7}{|l|}{ Lactate level } \\
\hline $0.30-1.60$ & 1.00 & & 1.00 & & 1.00 & \\
\hline $1.70-3.10$ & $1.75(1.21-2.53)$ & $0.003^{*}$ & $1.76(1.21-2.55)$ & $0.003^{*}$ & $1.50(1.00-2.25)$ & $0.048^{\star}$ \\
\hline $3.20-24.70$ & $3.40(2.41-4.82)$ & $<0.001^{*}$ & $3.53(2.48-5.02)$ & $<0.001^{\star}$ & $2.07(1.40-3.06)$ & $<0.001^{*}$ \\
\hline$p$ for trend & $1.86(1.57-2.20)$ & $<0.001^{*}$ & $1.89(1.59-2.25)$ & $<0.001^{*}$ & $1.43(1.18-1.73)$ & $<0.001^{*}$ \\
\hline \multicolumn{7}{|l|}{ Elderly } \\
\hline Lactate (mmol/L) & $1.11(1.06-1.17)$ & $<0.001^{*}$ & $1.12(1.06-1.17)$ & $<0.001^{*}$ & $1.03(0.98-1.08)$ & 0.290 \\
\hline \multicolumn{7}{|l|}{ Lactate level } \\
\hline $0.30-1.70$ & 1.00 & & 1.00 & & 1.00 & \\
\hline $1.80-3.00$ & $1.22(0.94-1.57)$ & 0.130 & $1.24(0.96-1.61)$ & 0.099 & $1.15(0.87-1.51)$ & 0.324 \\
\hline $3.10-17.40$ & $1.47(1.14-1.89)$ & $0.003^{*}$ & $1.50(1.16-1.94)$ & $0.002^{*}$ & $1.03(0.78-1.36)$ & 0.815 \\
\hline$p$ for trend & $1.21(1.07-1.37)$ & $0.003^{*}$ & $1.23(1.08-1.39)$ & $0.002^{\star}$ & $1.02(0.89-1.16)$ & 0.830 \\
\hline
\end{tabular}

${ }^{*} P<0.05$

Non-adjusted model adjust for: None

Adjust I model adjust for: age; gender; ethnicity.

Adjust II model adjust for: age; gender; first care unit; SAPSII.

Table 5. Subgroup analysis of the association between lactate and 28-day mortality in the two age groups. 


\begin{tabular}{|c|c|c|c|c|c|c|c|}
\hline \multirow[t]{2}{*}{ Subgroup } & \multicolumn{3}{|c|}{ Non-elderly } & \multirow[t]{2}{*}{ Subgroup } & \multicolumn{3}{|l|}{ Elderly } \\
\hline & Number & OR(95\% Cl) & $\begin{array}{l}\text { p for } \\
\text { interaction }\end{array}$ & & Number & OR(95\% Cl) & $\begin{array}{l}\text { p for } \\
\text { interaction }\end{array}$ \\
\hline Sex & & & 0.775 & Sex & & & 0.102 \\
\hline Male & 722 & $\begin{array}{l}1.27(1.19- \\
1.36)\end{array}$ & & Male & 856 & $\begin{array}{l}1.15(1.08- \\
1.22)\end{array}$ & \\
\hline Female & 527 & $\begin{array}{l}1.29(1.17- \\
1.42)\end{array}$ & & Female & 743 & $\begin{array}{l}1.06(0.98- \\
1.14)\end{array}$ & \\
\hline Ethnicity & & & 0.317 & Ethnicity & & & 0.278 \\
\hline White & 851 & $\begin{array}{l}1.32(1.22- \\
1.42)\end{array}$ & & White & 1247 & $\begin{array}{l}1.09(1.03- \\
1.15)\end{array}$ & \\
\hline Black & 137 & $\begin{array}{l}1.25(1.07- \\
1.46)\end{array}$ & & Black & 103 & $\begin{array}{l}1.24(1.02- \\
1.51)\end{array}$ & \\
\hline Asian & 40 & $\begin{array}{l}1.34(1.01- \\
1.76)\end{array}$ & & Asian & 50 & $\begin{array}{l}1.13(0.88- \\
1.46)\end{array}$ & \\
\hline Hispanic & 58 & $\begin{array}{l}1.72(1.14- \\
2.60)\end{array}$ & & Hispanic & 29 & $\begin{array}{l}1.42(0.98- \\
2.06)\end{array}$ & \\
\hline Other or unknown & 163 & $\begin{array}{l}1.18(1.05- \\
1.33)\end{array}$ & & Other or unknown & 170 & $\begin{array}{l}1.20(1.04- \\
1.40)\end{array}$ & \\
\hline First care unit & & & 0.141 & First care unit & & & 0.485 \\
\hline MICU & 852 & $\begin{array}{l}1.30(1.22- \\
1.40)\end{array}$ & & MICU & 1137 & $\begin{array}{l}1.09(1.03- \\
1.15)\end{array}$ & \\
\hline $\mathrm{CCU}$ & 84 & $\begin{array}{l}1.29(1.04- \\
1.60)\end{array}$ & & $\mathrm{CCU}$ & 131 & $\begin{array}{l}1.16(1.00- \\
1.34)\end{array}$ & \\
\hline TSICU & 87 & $\begin{array}{l}1.03(0.85- \\
1.25)\end{array}$ & & TSICU & 114 & $\begin{array}{l}1.18(0.98- \\
1.42)\end{array}$ & \\
\hline CSRU & 31 & $\begin{array}{l}0.83(0.33- \\
2.06)\end{array}$ & & CSRU & 50 & $\begin{array}{l}1.07(0.86- \\
1.34)\end{array}$ & \\
\hline SICU & 195 & $\begin{array}{l}1.34(1.16- \\
1.56)\end{array}$ & & SICU & 167 & $\begin{array}{l}1.24(1.06- \\
1.46)\end{array}$ & \\
\hline Admission type & & & 0.762 & Admission type & & & 0.858 \\
\hline Emergency & 1175 & $\begin{array}{l}1.27(1.20 \\
1.35)\end{array}$ & & Emergency & 1528 & $\begin{array}{l}1.11(1.06, \\
1.17)\end{array}$ & \\
\hline Elective & 50 & $\begin{array}{l}1.39(0.93 \\
2.08)\end{array}$ & & Elective & 52 & $\begin{array}{l}1.17(0.91 \\
1.52)\end{array}$ & \\
\hline Urgent & 24 & $\begin{array}{l}1.44(0.94 \\
2.19)\end{array}$ & & Urgent & 19 & $\begin{array}{l}1.21(0.78 \\
1.86)\end{array}$ & \\
\hline SAPSII & & & $0.020^{*}$ & SAPSII & & & 0.276 \\
\hline $11.00-28.00$ & 295 & $\begin{array}{l}1.52(1.03- \\
2.25)\end{array}$ & & $12.00-39.00$ & 391 & $\begin{array}{l}0.94(0.77- \\
1.14)\end{array}$ & \\
\hline $29.00-38.00$ & 299 & $\begin{array}{l}0.99(0.82- \\
1.20)\end{array}$ & & $40.00-48.00$ & 389 & $\begin{array}{l}0.99(0.88- \\
1.11)\end{array}$ & \\
\hline $39.00-51.00$ & 337 & $\begin{array}{l}1.09(0.99- \\
1.20)\end{array}$ & & $49.00-58.00$ & 415 & $\begin{array}{l}1.11(1.01- \\
1.22)\end{array}$ & \\
\hline $52.00-107.00$ & 318 & $\begin{array}{l}1.27(1.15- \\
1.40)\end{array}$ & & $59.00-110.00$ & 404 & $\begin{array}{l}1.05(0.97- \\
1.13)\end{array}$ & \\
\hline SOFA & & & $0.024^{*}$ & SOFA & & & 0.054 \\
\hline $0.00-3.00$ & 226 & $\begin{array}{l}1.85(1.28- \\
2.68)\end{array}$ & & $0.00-3.00$ & 261 & $\begin{array}{l}1.09(0.93- \\
1.29)\end{array}$ & \\
\hline $4.00-6.00$ & 347 & $\begin{array}{l}0.99(0.82- \\
1.19)\end{array}$ & & $4.00-6.00$ & 527 & $\begin{array}{l}0.94(0.83- \\
1.06)\end{array}$ & \\
\hline $7.00-9.00$ & 308 & $\begin{array}{l}1.18(1.05- \\
1.32)\end{array}$ & & $7.00-8.00$ & 321 & $\begin{array}{l}1.04(0.93- \\
1.15)\end{array}$ & \\
\hline
\end{tabular}

Page 11/16 


\begin{tabular}{|c|c|c|c|c|c|c|c|}
\hline $10.00-21.00$ & 368 & $\begin{array}{l}1.17(1.09- \\
1.27)\end{array}$ & & $9.00-21.00$ & 490 & $\begin{array}{l}1.13(1.05- \\
1.21)\end{array}$ & \\
\hline QSOFA & & & 0.621 & QSOFA & & & 0.470 \\
\hline 0 & 13 & $\begin{array}{l}0.88(0.32 \\
2.39)\end{array}$ & & 0 & 10 & $\begin{array}{l}1.00(0.00 \\
\text { inf.) }\end{array}$ & \\
\hline 1 & 161 & $\begin{array}{l}1.16(0.93 \\
1.44)\end{array}$ & & 1 & 184 & $\begin{array}{l}1.00(0.85 \\
1.18)\end{array}$ & \\
\hline 2 & 884 & $\begin{array}{l}1.27(1.19 \\
1.35)\end{array}$ & & 2 & 1006 & $\begin{array}{l}1.14(1.07 \\
1.21)\end{array}$ & \\
\hline 3 & 191 & $\begin{array}{l}1.33(1.16 \\
1.52)\end{array}$ & & 3 & 399 & $\begin{array}{l}1.09(0.99 \\
1.19)\end{array}$ & \\
\hline SIRS & & & 0.432 & SIRS & & & $0.049^{*}$ \\
\hline 0 & 2 & $\begin{array}{l}1.00(0.00- \\
\text { Inf) }\end{array}$ & & 0 & 1 & $\begin{array}{l}0.00(0.00- \\
\text { inf.) }\end{array}$ & \\
\hline 1 & 32 & $\begin{array}{l}0.70(0.28- \\
1.75)\end{array}$ & & 1 & 36 & $\begin{array}{l}1.65(0.99- \\
2.77)\end{array}$ & \\
\hline 2 & 125 & $\begin{array}{l}1.20(0.98- \\
1.46)\end{array}$ & & 2 & 211 & $\begin{array}{l}1.30(1.09- \\
1.55)\end{array}$ & \\
\hline 3 & 441 & $\begin{array}{l}1.35(1.21- \\
1.50)\end{array}$ & & 3 & 623 & $\begin{array}{l}1.05(0.96- \\
1.14)\end{array}$ & \\
\hline 4 & 649 & $\begin{array}{l}1.27(1.18- \\
1.36)\end{array}$ & & 4 & 728 & $\begin{array}{l}1.10(1.04- \\
1.17)\end{array}$ & \\
\hline \multicolumn{8}{|l|}{ Major comorbidities } \\
\hline Hypertension & & & 0.699 & Hypertension & & & 0.257 \\
\hline No & 749 & $\begin{array}{l}1.29(1.20- \\
1.39)\end{array}$ & & No & 617 & $\begin{array}{l}1.08(1.01- \\
1.16)\end{array}$ & \\
\hline Yes & 500 & $\begin{array}{l}1.26(1.16- \\
1.37)\end{array}$ & & Yes & 982 & $\begin{array}{l}1.14(1.07- \\
1.22)\end{array}$ & \\
\hline Liver cirmosis & & & $0.027^{\star}$ & Liver cirrhosis & & & 0.874 \\
\hline No & 1053 & $\begin{array}{l}1.28(1.19- \\
1.36)\end{array}$ & & No & 1522 & $\begin{array}{l}1.11(1.06- \\
1.16)\end{array}$ & \\
\hline Yes & 196 & $\begin{array}{l}1.10(0.99- \\
1.22)\end{array}$ & & Yes & 77 & $\begin{array}{l}1.12(0.95- \\
1.33)\end{array}$ & \\
\hline Congestive heart failure & & & 0.246 & Congestive heart failure & & & 0.087 \\
\hline No & 1021 & $\begin{array}{l}1.30(1.22- \\
1.38)\end{array}$ & & No & 911 & $\begin{array}{l}1.15(1.09- \\
1.23)\end{array}$ & \\
\hline Yes & 228 & $\begin{array}{l}1.19(1.04- \\
1.36)\end{array}$ & & Yes & 688 & $\begin{array}{l}1.06(0.99- \\
1.14)\end{array}$ & \\
\hline $\begin{array}{l}\text { Chronic renal } \\
\text { insufficiency }\end{array}$ & & & 0.361 & $\begin{array}{l}\text { Chronic renal } \\
\text { insufficiency }\end{array}$ & & & 0.266 \\
\hline No & 513 & $\begin{array}{l}1.32(1.18- \\
1.47)\end{array}$ & & No & 522 & $\begin{array}{l}1.05(0.95- \\
1.16)\end{array}$ & \\
\hline Yes & 736 & $\begin{array}{l}1.24(1.16- \\
1.32)\end{array}$ & & Yes & 1077 & $\begin{array}{l}1.12(1.06- \\
1.18)\end{array}$ & \\
\hline $\begin{array}{l}\text { Cerebrovascular } \\
\text { disease }\end{array}$ & & & 0.786 & $\begin{array}{l}\text { Cerebrovascular } \\
\text { disease }\end{array}$ & & & 0.645 \\
\hline No & 1160 & $\begin{array}{l}1.28(1.21 \\
1.36)\end{array}$ & & No & 1440 & $\begin{array}{l}1.12(1.06, \\
1.17)\end{array}$ & \\
\hline Yes & 89 & $\begin{array}{l}1.24(1.00 \\
1.54)\end{array}$ & & Yes & 159 & $\begin{array}{l}1.08(0.93 \\
1.25)\end{array}$ & \\
\hline Diabetes mellitus & & & 0.584 & Diabetes mellitus & & & 0.825 \\
\hline
\end{tabular}




\begin{tabular}{|c|c|c|c|c|c|c|c|}
\hline No & 922 & $\begin{array}{l}1.29(1.21- \\
1.38)\end{array}$ & & No & 1045 & $\begin{array}{l}1.12(1.06- \\
1.18)\end{array}$ & \\
\hline Yes & 327 & $\begin{array}{l}1.25(1.12- \\
1.38)\end{array}$ & & Yes & 554 & $\begin{array}{l}1.11(1.02- \\
1.20)\end{array}$ & \\
\hline Malignancy & & & 0.584 & Malignancy & & & 0.600 \\
\hline No & 1100 & $\begin{array}{l}1.26(1.18- \\
1.34)\end{array}$ & & No & 1371 & $\begin{array}{l}1.10(1.05- \\
1.16)\end{array}$ & \\
\hline Yes & 149 & $\begin{array}{l}1.32(1.13- \\
1.53)\end{array}$ & & Yes & 228 & $\begin{array}{l}1.14(1.01- \\
1.29)\end{array}$ & \\
\hline $\begin{array}{l}\text { Major source of } \\
\text { infection }\end{array}$ & & & & $\begin{array}{l}\text { Major source of } \\
\text { infection }\end{array}$ & & & \\
\hline Respiratory tract & & & 0.088 & Respiratory tract & & & $0.036^{*}$ \\
\hline No & 885 & $\begin{array}{l}1.32(1.23- \\
1.41)\end{array}$ & & No & 1062 & $\begin{array}{l}1.16(1.09- \\
1.22)\end{array}$ & \\
\hline Yes & 364 & $\begin{array}{l}1.18(1.05- \\
1.31)\end{array}$ & & Yes & 537 & $\begin{array}{l}1.04(0.95- \\
1.13)\end{array}$ & \\
\hline Urinary tract & & & 1.000 & Urinary tract & & & 0.844 \\
\hline No & 1205 & $\begin{array}{l}1.27(1.20 \\
1.34)\end{array}$ & & No & 1550 & $\begin{array}{l}1.12(1.06 \\
1.17)\end{array}$ & \\
\hline Yes & 44 & $\begin{array}{l}1.00(0.00 \\
\text { inf.) }\end{array}$ & & Yes & 49 & $\begin{array}{l}1.07(0.70 \\
1.64)\end{array}$ & \\
\hline Skin and soft tissue & & & 0.109 & Skin and soft tissue & & & 0.966 \\
\hline No & 1110 & $\begin{array}{l}1.29(1.22- \\
1.37)\end{array}$ & & No & 1485 & $\begin{array}{l}1.11(1.06- \\
1.17)\end{array}$ & \\
\hline Yes & 139 & $\begin{array}{l}1.06(0.84- \\
1.35)\end{array}$ & & Yes & 114 & $\begin{array}{l}1.12(0.94- \\
1.33)\end{array}$ & \\
\hline Intra-abdomen & & & $0.003^{*}$ & Intra-abdomen & & & 0.656 \\
\hline No & 1042 & $\begin{array}{l}1.22(1.15- \\
1.30)\end{array}$ & & No & 1338 & $\begin{array}{l}1.12(1.06- \\
1.18)\end{array}$ & \\
\hline Yes & 207 & $\begin{array}{l}1.54(1.33- \\
1.79)\end{array}$ & & Yes & 261 & $\begin{array}{l}1.08(0.95- \\
1.23)\end{array}$ & \\
\hline
\end{tabular}

${ }^{*} P<0.05$

Figures 


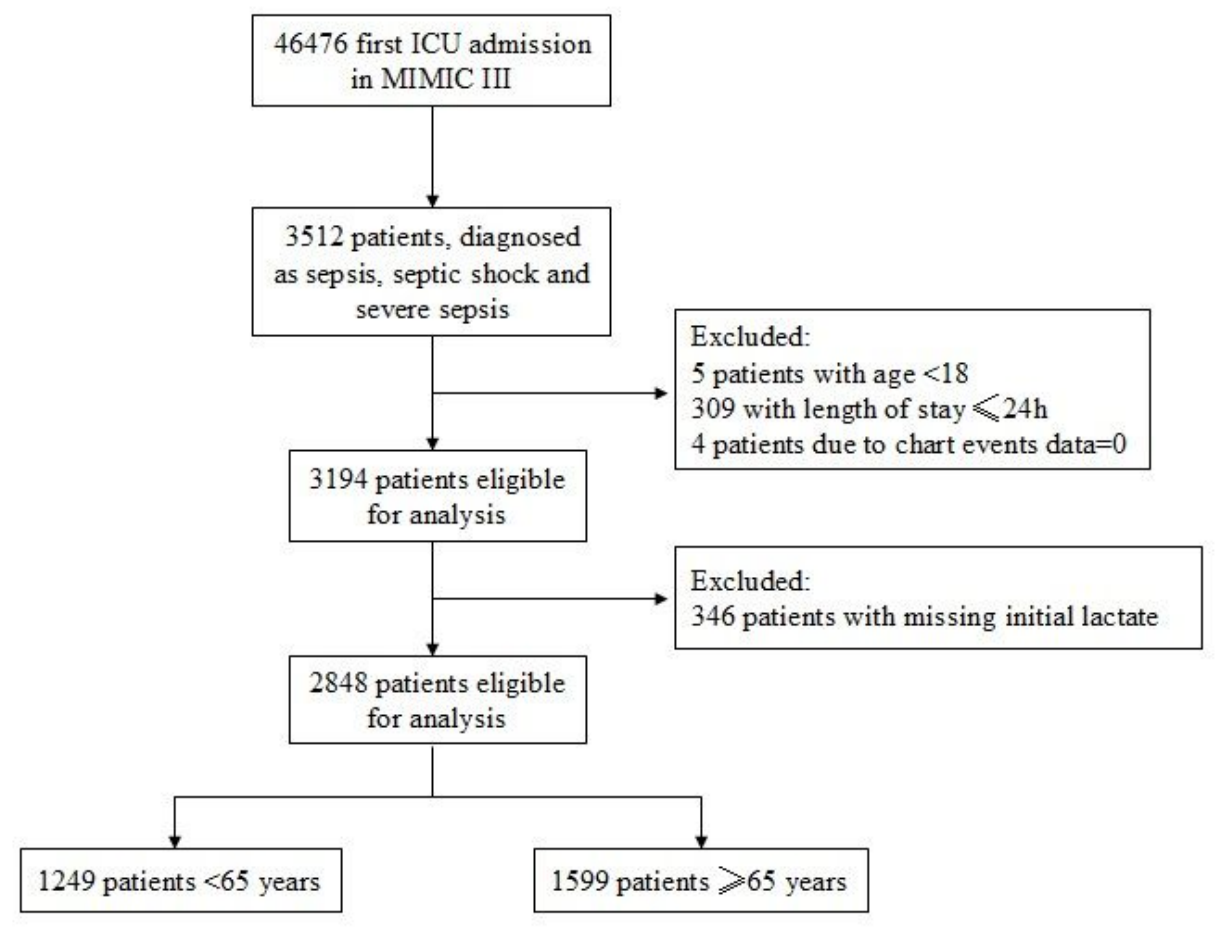

Figure 1

Patient disposition.

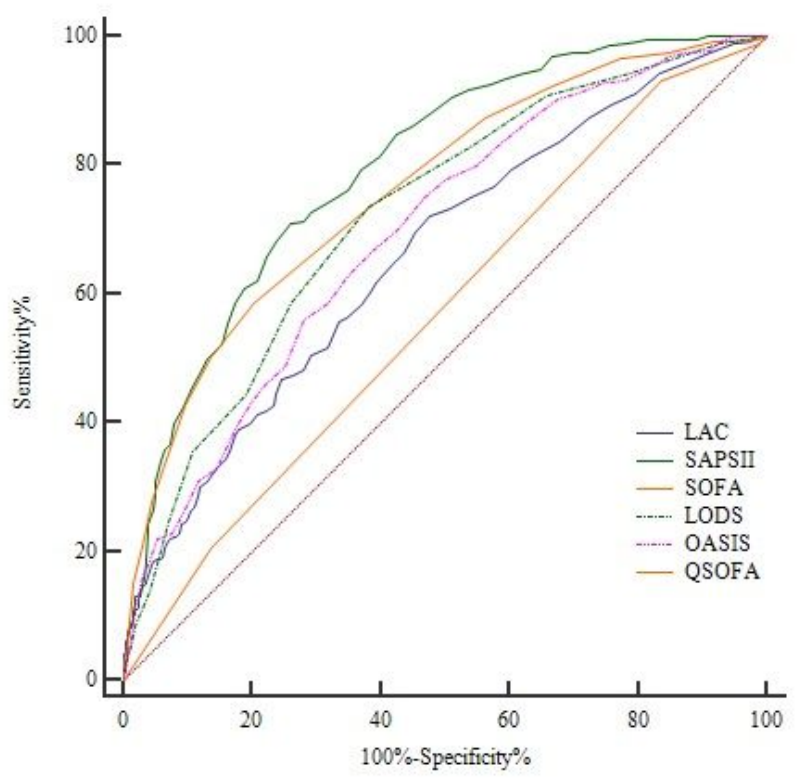

Figure 2

Receiver operating characteristic curves for predicting 28-day mortality in non-elderly patients. 


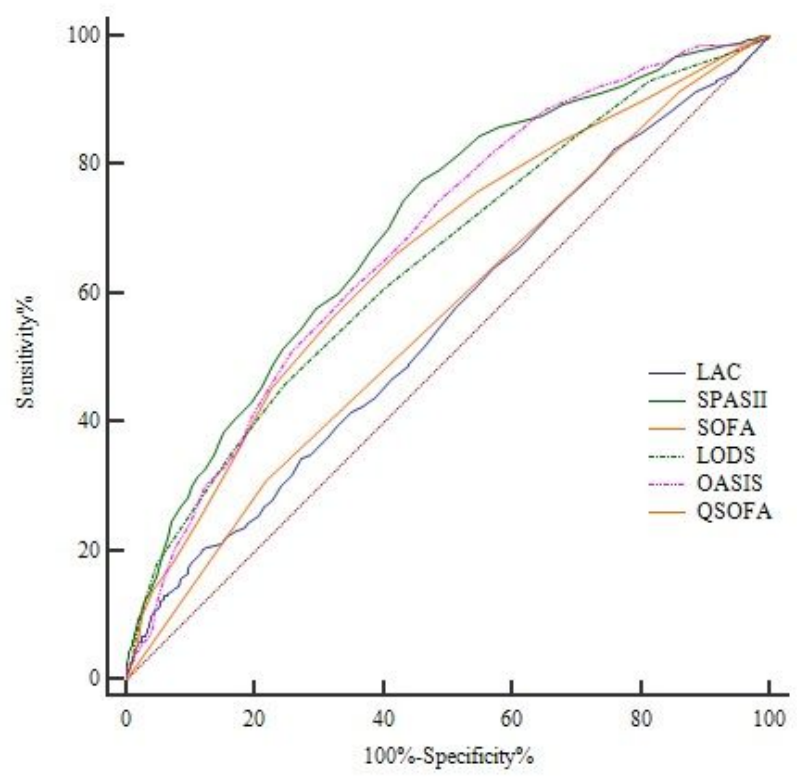

Figure 3

Receiver operating characteristic curves for predicting 28-day mortality in elderly patients.

$\begin{array}{lc}\text { Subgroup } & \text { Number } \\ \text { Sex } & \\ \text { Male } & 722 \\ \text { Female } & 527 \\ \text { Ethnicity } & \\ \text { White } & 851 \\ \text { Black } & 137 \\ \text { Asian } & 40 \\ \text { Hispanic } & 58 \\ \text { Other or unknown } & 163 \\ \text { First care unit } & \\ \text { MICU } & 852 \\ \text { CCU } & 84 \\ \text { TSICU } & 87 \\ \text { CSRU } & 31 \\ \text { SICU } & 195 \\ \text { SAPSII } & \\ 11.00-28.00 & 295 \\ 29.00-38.00 & 299 \\ 39.00-51.00 & 337 \\ 52.00-107.00 & 318 \\ \text { SOFA } & \\ 0.00-3.00 & 226 \\ 4.00-6.00 & 347 \\ 7.00-9.00 & 308 \\ 10.00-21.00 & 368 \\ \text { OASIS } & \\ 13.00-30.00 & 391 \\ 31.00-39.00 & 423 \\ 40.00-63.00 & 435 \\ & \end{array}$

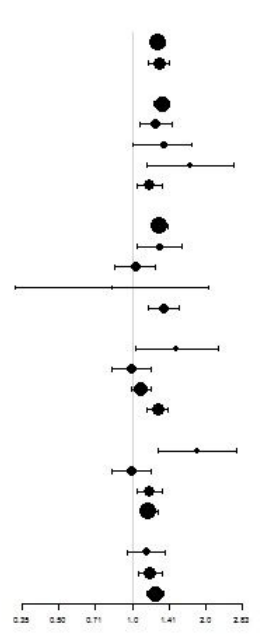

OR(95\% Cl)
$1.27(1.19,1.36)$
$1.29(1.17,1.42)$
$1.32(1.22,1.42)$
$1.25(1.07,1.46)$
$1.34(1.01,1.76)$
$1.72(1.14,2.60)$
$1.18(1.05,1.33)$
$1.30(1.22,1.40)$
$1.29(1.04,1.60)$
$1.03(0.85,1.25)$
$0.83(0.33,2.06)$
$1.34(1.16,1.56)$
$1.52(1.03,2.25)$
$0.99(0.82,1.20)$
$1.09(0.99,1.20)$
$1.27(1.15,1.40)$
$1.85(1.28,2.68)$
$0.99(0.82,1.19)$
$1.18(1.05,1.32)$
$1.17(1.09,1.27)$
$1(0.95,1.37) 0.1680$
$18(1.06,1.32) 0.0030$
$4(1.15,1.34)<0.0001$

p for interaction

0.7749

0.3168

0.141

0.0198

0.0243

0.5957

\begin{tabular}{|c|c|c|c|c|}
\hline $\begin{array}{l}\text { Subgroup } \\
\text { SIRS }\end{array}$ & Number & & $\mathrm{OR}(95 \% \mathrm{Cl})$ & $\begin{array}{l}\mathrm{p} \text { for interaction } \\
0.4318\end{array}$ \\
\hline 1 & 32 & & $0.70(0.28,1.75)$ & \\
\hline & 125 & 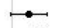 & $1.20(0.98,1.46)$ & \\
\hline 3 & 441 & $\infty$ & $1.35(1.21,1.50)$ & \\
\hline 4 & 649 & & $1.27(1.18,1.36)$ & \\
\hline Hypertension & & & & 0.6985 \\
\hline & 749 & - & $1.29(1.20,1.39)$ & \\
\hline $\begin{array}{l}\text { Yes } \\
\text { Liver cirrhosis }\end{array}$ & 500 & - & $1.26(1.16,1.37)$ & 0.0266 \\
\hline No & 1053 & - & $1.28(1.19,1.36)$ & \\
\hline Yes & 196 & $\bullet$ & $1.10(0.99,1.22)$ & \\
\hline $\begin{array}{l}\text { Congestive heart failure } \\
\text { No }\end{array}$ & & & & 0.2459 \\
\hline $\begin{array}{l}\text { No } \\
\text { Yes }\end{array}$ & $\begin{array}{l}1021 \\
228\end{array}$ & $\rightarrow \infty$ & $1.19(1.04,1.36)$ & \\
\hline $\begin{array}{l}\text { Chronic renal insufficiency } \\
\text { No }\end{array}$ & 513 & $\sim \infty$ & $1.32(1.18,1.47)$ & 0.361 \\
\hline Yes & 736 & & $1.24(1.16,1.32)$ & \\
\hline Malignancy & & & & 0.5844 \\
\hline No & 1100 & - & $1.26(1.18,1.34)$ & \\
\hline $\begin{array}{l}\text { Yes } \\
\text { Major source of infection }\end{array}$ & 149 & $\bullet-$ & $1.32(1.13,1.53)$ & \\
\hline Respiratory tract & & & & 0.0884 \\
\hline $\begin{array}{l}\text { No } \\
\text { Yes }\end{array}$ & $\begin{array}{l}885 \\
364\end{array}$ & $\bullet$ & $1.32(1.23,1.41)$ & \\
\hline Skin and soft tissue & 364 & & $1.18(1.05,1.31)$ & 0.1091 \\
\hline No & 1110 & - & $1.29(1.22,1.37)$ & \\
\hline Yes & 139 & & $1.06(0.84,1.35)$ & \\
\hline $\begin{array}{l}\text { Intra-abdomen } \\
\text { No }\end{array}$ & 1042 & & $1.22(1.15,1.30)$ & 0.0026 \\
\hline Yes & 207 & & $1.54(1.33,1.79)$ & \\
\hline
\end{tabular}

Figure 4 
Subgroup analysis of the association between lactate and 28-day mortality in non-elderly patients.

Page 16/16 